\title{
Globin Gene Expression in Erythroid Human Fetal Liver Cells
}

Timothy J. Ley, * Kathleen A. Maloney, ${ }^{*}$ Jeffrey I. Gordon, ${ }^{*}$ and Alan L. Schwartz ${ }^{5}$

*Division of Hematology-Oncology, Departments of Medicine and Genetics, Jewish Hospital at Washington University Medical Center, ${ }^{\ddagger}$ Division of Gastroenterology, Departments of Medicine and Biochemistry, and ${ }^{\S}$ Division of Hematology-Oncology,

Edward Mallinckrodt Department of Pediatrics and Department of Pharmacology,

Washington University Medical School, St. Louis, Missouri 63110

\begin{abstract}
We measured steady-state levels of the human globin mRNAs in liver samples from several mid-gestational fetuses. RNA from the $\epsilon, \gamma, \beta, \zeta, \theta$, and $\alpha$ globin genes were present in fetal liver samples isolated from 10-25-wk embryos. The abundance of all human globin mRNAs declined in older fetuses, presumably because of a gradual reduction in the proportion of erythroid precursors in the liver as development procedes. The $\gamma: \beta$ globin mRNA ratio in 10-18-wk fetal erythroblasts was 6-7:1, and in adult erythroid bone marrow the ratio was 0.02:1. In fetal liver samples, the relative abundance of $\epsilon$ transcripts was $<1 \%$ that of $\gamma$, and $\zeta$ transcripts $<5 \%$ that of $\alpha$. Embryonic transcripts declined in abundance during late fetal development and were not detected in newborn liver or adult erythroid bone marrow. $\theta$ globin $\mathrm{mRNA}$ also represented a minor species $(<1 \%$ that of $\alpha)$ in fetal liver samples, but in contrast to the embryonic mRNAs, was most abundant in adult marrow samples obtained from patients with erythroid hyperplasia. These results support the hypothesis that globin protein levels are regulated by the relative amounts of each globin mRNA at various stages of erythropoietic development.
\end{abstract}

\section{Introduction}

The human $\beta$-like globin genes $\left(5^{\prime}-\epsilon_{-}^{\mathrm{G}} \gamma-{ }^{\mathrm{A}} \gamma-\psi \beta-\delta-\beta-3^{\prime}\right)$ are located on the short arm of chromosome 11 and are expressed consecutively during development. The human $\alpha$-like genes $\left(5^{\prime}-\zeta-\psi \zeta_{1}-\psi \alpha_{2}-\psi \alpha_{1}-\alpha_{2}-\alpha_{1}-\theta_{1}-3^{\prime}\right)$ are located on the long arm of chromosome 16 , and are also developmentally regulated $(1,2)$. The embryonic globin genes, $\epsilon$ and $\zeta$, are transcriptionally active in yolk sac-derived erythroblasts (3). When hematopoiesis shifts to the liver at 5-9 wk of development, these megaloblastic yolk sac-derived red cells stop being produced, since the yolk sac becomes atretic and involutes at this time (4). Erythroid precursors derived from early fetal livers contain hypomethylated and transcriptionally active $\gamma$-globin genes (5-7), and fetal hemoglobin $\left(\alpha_{2} \gamma_{2}\right)$ is the predominant hemoglobin formed during the entire period of fetal erythropoiesis $(1,2,8)$. However, the "adult" $\beta$-globin gene must also be actively expressed in fetal erythroblasts, since a number of investigators have shown that hemoglobin $\mathrm{A}\left(\alpha_{2} \beta_{2}\right)$ comprises $5-15 \%$ of the newly synthesized hemoglobin in fetuses as young as 10 weeks (8-13). Changes in rates of globin biosyn-

Received for publication 22 July 1988 and in revised form 26 September 1988.

J. Clin. Invest.

(C) The American Society for Clinical Investigation, Inc

0021-9738/89/03/1032/07 \$2.00

Volume 83, March 1989, 1032-1038 thesis at various stages of development are probably due to changes in the rates of transcription of each of the globin genes at "appropriate" developmental times. However, this hypothesis has not yet been directly tested, since intact fetal livers from several stages of development have not been widely available for RNA analysis.

We performed this study to define steady-state levels of globin mRNAs present in fetal livers at mid- to late gestation. Our results show that relative amounts of embryonic, fetal, and adult hemoglobins are probably determined by the relative concentrations of corresponding globin mRNAs at various stages of development, implying that these events may be controlled by the rates of transcription of each of these genes. The embryonic globin genes $(\epsilon$ and $\zeta$ ) are minimally expressed in early fetal livers, gradually declining to undetectable levels in adult bone marrow. In contrast, the newly discovered $\theta$ globin gene (14-18) produces very low levels of mRNA in fetal and adult erythroid cells.

\section{Methods}

Human liver samples. Normal adult human liver was obtained at the time of organ donation (19). Before death, there was no history or clinical evidence of hepatic or hematopoietic dysfunction. Liver tissue was removed, immediately frozen in liquid nitrogen, and maintained at $-90^{\circ} \mathrm{C}$ for $2-4$ yr. Fetal liver samples from first trimester and midgestation aborted fetuses were obtained as previously described (20). Newborn liver was obtained at the time of death after acute hypoxia. Tissues were maintained at $-90^{\circ} \mathrm{C}$ for $15-20 \mathrm{yr}$. These tissues had previously been used for the preparation of RNA that translated with fidelity in vitro (21). Fetal age was estimated from measured crownrump lengths, according to the nomograms of Tanimura (see Schwartz et al. [19]).

Tissue culture. $\mathrm{K} 562$ cells were maintained in modified Iscove's MEM with $10 \%$ fetal calf serum and $50 \mu \mathrm{g} / \mathrm{ml}$ gentimycin in $5 \% \mathrm{CO}_{2}$ at $37^{\circ} \mathrm{C}$ with $100 \%$ humidity. The cells used for this study were shown to have a rearranged and sixfold-amplified $b c r$ locus $(22,23)$, consistent with their origin from a patient with chronic myelogenous leukemia. Cells were induced in the presence of $20 \mu \mathrm{M}$ hemin for $2 \mathrm{~d}$ before harvesting.

$R N A$ preparation. Fetal liver samples, adult bone marrow cells, or tissue culture cells were dissolved in $10 \mathrm{ml}$ of a cocktail containing $4 \mathrm{M}$ guanidinium thiocyanate, $25 \mathrm{mM}$ sodium citrate, $\mathrm{pH} 7.0,0.5 \%$ sarcosyl, and $0.1 \mathrm{M} \beta$-mercaptoethanol. Total cellular RNA was prepared from these samples as previously described (24).

Probe preparation. Probes were prepared for $S_{1}$ nuclease analysis by cutting with appropriate restriction endonucleases (U.S. Biochemical Corp., Cleveland, $\mathrm{OH}$ ), dephosphorylating with calf intestinal phosphatase (Pharmacia Fine Chemicals, Piscataway, NJ), and labeling with $\left[\gamma^{32}\right.$ P]ATP (ICN, Plainview, NY; $>3,000 \mathrm{Ci} / \mathrm{mM}$ ) and cloned polynucleotide kinase (U.S. Biochemical Corp.). The labeled $5^{\prime}$ ends of all probes had four base $5^{\prime}$ overhangs, and were labeled to a specific activity of approximately $5 \times 10^{6} \mathrm{cpm} / \mu \mathrm{g}$ of input DNA. Random primer-labeling of probes for the RNA slot blot analysis was performed as described (25). 
Cloned genomic DNA fragments used in this study included the following: $\epsilon, 0.67-\mathrm{kb}$ Bam HI 5' $\epsilon$ fragment; $\gamma, 1.7-\mathrm{kb}$ EcoRI-Bam HI $5^{\prime}$ ${ }^{\mathrm{A}} \gamma$ fragment; $\beta, 1.9-\mathrm{kb}$ Bam HI $5^{\prime} \beta$ fragment; $\zeta, 0.66-\mathrm{kb}$ EcoRI-Bgl II $5^{\prime}$ $\zeta$ fragment; $\underline{\alpha}$, 1.0-kb Pst I-Hind III $5^{\prime} \alpha_{2}$ fragment; and $\underline{\theta}, 0.9-\mathrm{kb}$ Bam HI $5^{\prime} \theta$ fragment. Probes used for the slot blot analysis included a 1.9-kb Bam HI fragment containing human $\beta$-actin cDNA (26), a 0.6-kb EcoRI fragment containing human ceruloplasmin cDNA (27), and a 1.5-kb Sac I genomic c-myc fragment containing parts of introns I and II and all of exon 2 of the human c-myc gene (28).

$S_{1}$ nuclease analysis. 2.5 or $20 \mu \mathrm{g}$ of total cellular RNA derived from various samples was hybridized with $50,000-100,000 \mathrm{cpm}$ (10-20 ng of probe DNA) in $15 \mu \mathrm{l}$ of hybridization cocktail $(80 \%$ formamide, $0.4 \mathrm{M} \mathrm{NaCl}, 40 \mathrm{mM}$ Pipes, $\mathrm{pH}$ 6.4, and $1 \mathrm{mM}$ EDTA) at $52^{\circ} \mathrm{C}$ overnight (29). All assays were performed in probe excess. Samples were then treated with 150 units of $S_{1}$ nuclease (Sigma Chemical Co., St. Louis, MO) at $37^{\circ} \mathrm{C}$ for $30 \mathrm{~min}$, ethanol precipitated with carrier Escherichia coli tRNA, and quantitatively loaded onto denaturing $8 \%$ sequencing gels. All experiments were performed at least twice, with identical results.

RNA slot blot analysis. $15 \mu \mathrm{g}$ of total cellular RNA was dissolved in $6 \times \mathrm{SSC} / 7.4 \%$ formaldehyde, denatured at $60^{\circ} \mathrm{C}$ for $15 \mathrm{~min}$, and slotted in triplicate onto nitrocellulose prewetted with $\mathrm{H}_{2} \mathrm{O}$ followed by $20 \times$ SSC. The filter was baked for $20 \mathrm{~min}$, and prehybridized in a solution containing $5 \times \mathrm{SSC}, 5 \times$ Denhardt's solution, $50 \mathrm{mM}$ $\mathrm{NaHPO}_{4}, \mathrm{pH} 7.5,0.1 \%$ SDS, 50\% formamide (Fluka, Ronkonkoma, $\mathrm{NY}$ ), and $100 \mu \mathrm{g} / \mathrm{ml}$ denatured sonicated salmon sperm DNA for $2 \mathrm{~h}$ at $42^{\circ} \mathrm{C}$. Random primer labeled probes were added to a final concentration of $1 \times 10^{6} \mathrm{cpm} / \mathrm{ml}$, and hybridization was allowed to proceed overnight at $42^{\circ} \mathrm{C}$. The filters were washed twice with $2 \times \mathrm{SSC} / 0.1 \%$ SDS for $15 \mathrm{~min}$ at room temperature, and twice with $0.1 \times \mathrm{SSC} / 0.1 \%$ SDS for $15 \mathrm{~min}$ at $55^{\circ} \mathrm{C}$ before being autoradiographed overnight at $-70^{\circ} \mathrm{C}$.

\section{Results}

We first measured the relative abundance of $\epsilon, \gamma$, and $\beta$ globin mRNAs in fetal and adult erythroid tissues. The organization of the probes used for these analyses are shown at the bottom of Fig. 1. $\epsilon, \gamma$, and $\beta$ globin exon 2 sequences are $77-87 \%$ conserved, and each contains a Bam HI site 209 nucleotides $(\mathrm{nt})^{1}$ from the $5^{\prime}$ end of this exon on the noncoding strand. Correctly processed $\epsilon, \gamma$, or $\beta$ globin exon 2 mRNAs would be expected to protect probe fragments of $209 \mathrm{nt}$ from $S_{1}$ digestion; the positions of these fragments are indicated on the right side of the figure. Despite considerable homology of $\epsilon, \gamma$, and $\beta$ exon 2 , each probe is absolutely specific for its mRNA using these hybridization conditions.

$20 \mu \mathrm{g}$ of total cellular RNA from all samples was hybridized with the $\epsilon$ probe, or $2.5 \mu \mathrm{g}$ of total cellular RNA was hybridized with the $\gamma$ or $\beta$ globin probes. After $S_{1}$ nuclease treatment and electrophoresis of protected probe fragments, the gels were autoradiographed for $5 \mathrm{~d}(\epsilon)$ or $1 \mathrm{~d}(\gamma$ and $\beta)$. The relative sensitivity of the $S_{1}$ assays is therefore approximately $\times 40$ for $\epsilon$, and $\times 1$ for $\gamma$ and $\beta$ globin mRNAs. The relative abundance of $\epsilon$ globin mRNA was very low compared with $\gamma$ mRNA, and only the earliest fetal liver samples (weeks 10 and 13) contained significant amounts of $\epsilon$ mRNA (compare upper and middle panels of Fig. 1). Small amounts of $\epsilon$ mRNA were present in uninduced K562 cells, and increased strikingly after $2 \mathrm{~d}$ of hemin treatment. No $\epsilon$ mRNA was detected in adult erythroid bone marrow RNA derived from a patient with homozygous sickle cell anemia.

1. Abbreviation used in this paper: $\mathrm{nt}$, nucleotide(s).
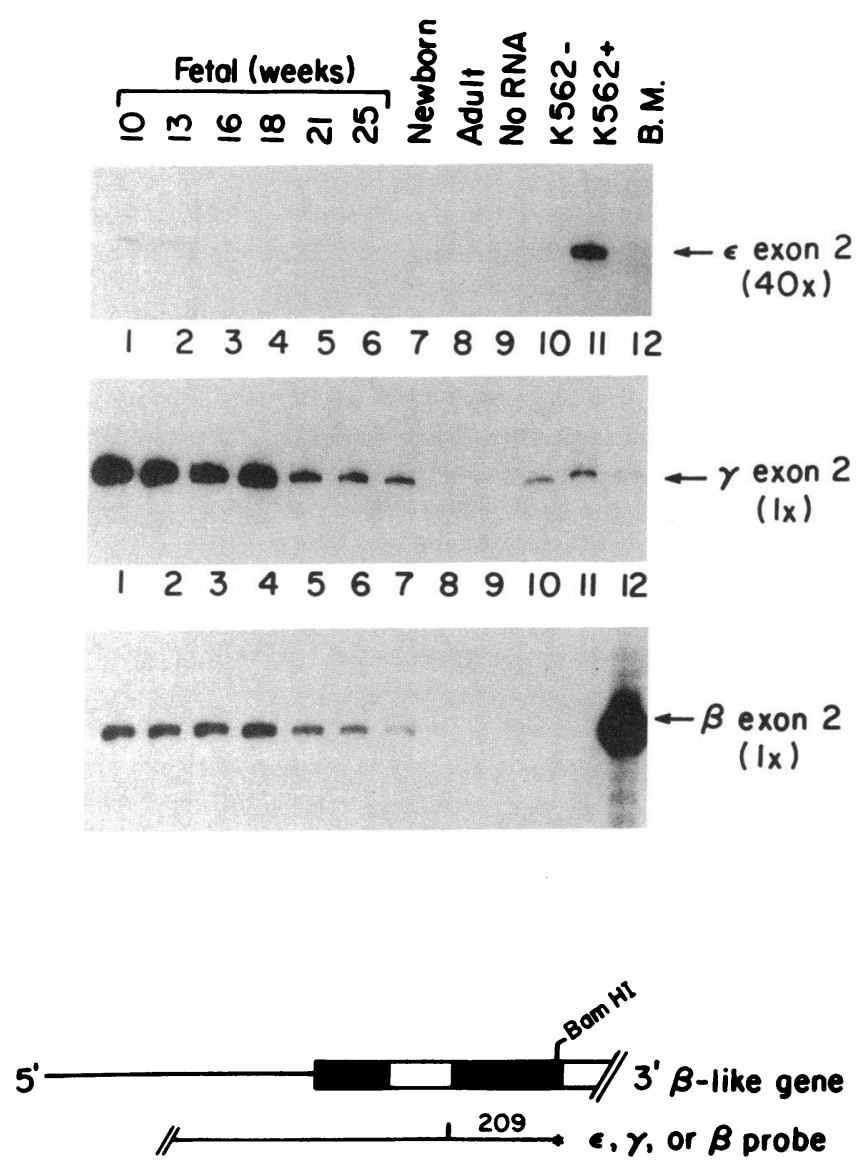

Figure 1. $S_{1}$ nuclease protection analysis of $\epsilon, \gamma$, and $\beta$ globin mRNAs. The organization of the probes used for this study is shown at the bottom of the figure. Exons are shown as black boxes, introns as open boxes, and $5^{\prime}$ flanking sequence as a thin line. The position of a Bam HI site in exon 2 is indicated. The probe fragment protected by correctly spliced $\epsilon, \gamma$, or $\beta$ globin mRNA is shown, and the positions of correctly spliced $\mathrm{mRNAs}$ are indicated on the right side of each panel. $20 \mu \mathrm{g}$ of total cellular RNA was hybridized with the $\epsilon$ gene probe (top). $2.5 \mu \mathrm{g}$ of total cellular RNA was hybridized with the $\gamma$ probe (middle) or the $\beta$ probe (bottom). After hybridization and $S_{1}$ nuclease treatment, protected probe fragments were electrophoresed on $8 \%$ denaturing sequencing gels, and autoradiography was performed at $-70^{\circ} \mathrm{C}$ for $5 \mathrm{~d}$ ( $\epsilon$ probe) or $1 \mathrm{~d}(\gamma$ and $\beta$ probes). The relative sensitivity of each assay is therefore $\times 40$ for the $\epsilon$ probe, or $\times 1$ for $\gamma$ and $\beta$. The age of each fetal liver sample was estimated from the crown-rump length of the abortus (19). (K562-) RNA derived from uninduced K562 cells; $(K 562+)$ RNA derived from cells induced for $2 \mathrm{~d}$ with $20 \mu \mathrm{M}$ hemin; (B.M.) bone marrow RNA derived from a patient with homozygous sickle cell anemia.

$\gamma$-Globin mRNA was abundant in all of the fetal liver samples tested. The relative abundance of $\gamma$ mRNA per microgram of total cellular RNA was greatest early in development. In samples obtained at late stages of fetal development (weeks 21-25), the relative abundance of $\gamma$ globin mRNA declined. No $\gamma$ globin mRNA was detected in an adult liver sample. $\gamma$ globin mRNA was relatively abundant in $\mathrm{K} 562$ cells, comparable to that observed in 25-wk liver RNA. $\gamma$ globin mRNA levels increased slightly after $2 \mathrm{~d}$ of hemin treatment. The level of $\gamma$ globin mRNA in adult erythroid marrow was less than that of K562 cells. The sickle cell anemia patient 


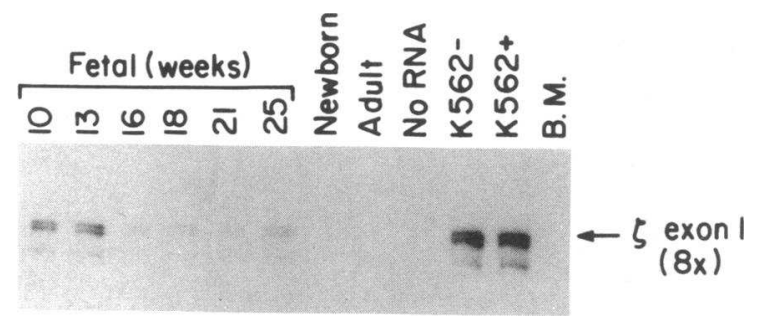

$|2345678910| \mid 12$
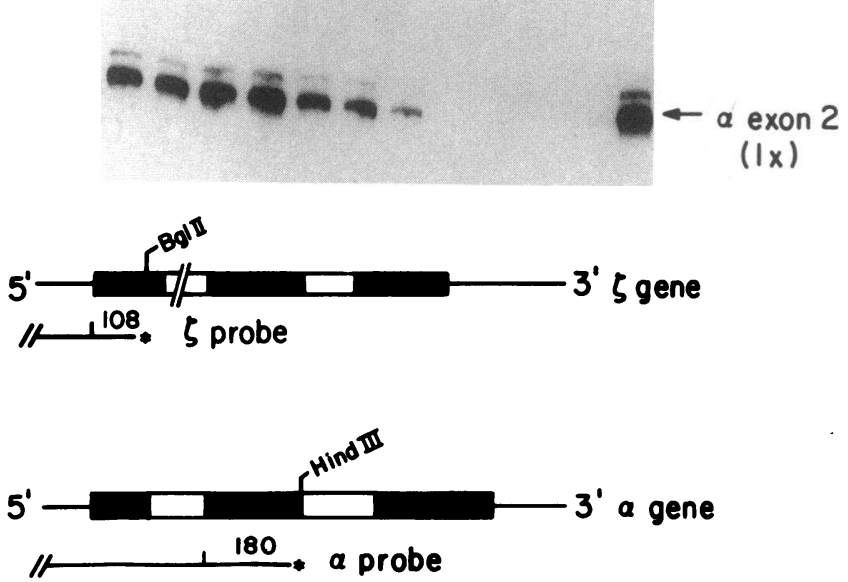

Figure $2 . \mathrm{S}_{1}$ nuclease protection analysis of $\zeta$ and $\alpha$ globin mRNAs. The organization of the $\zeta$ and $\alpha$ globin genes and probes derived from these genes are shown in the bottom of this figure. The $\zeta$ globin probe was annealed with $20 \mu \mathrm{g}$ of total cellular RNA. $2.5 \mu \mathrm{g}$ of total cellular RNA was hybridized with the $\alpha$ globin probe. Analysis was performed as described in Fig. 1. Autoradiographs were exposed for one day. Additional bands present below and above the expected bands are reproducibly present but of uncertain significance; they may represent artifacts of $S_{1}$ nuclease digestion. The intensity of these bands is always proportional to that of the expected band.

from whom this sample was obtained has $\sim 2 \%$ fetal hemoglobin in his circulating red blood cells.

$\beta$-Globin mRNA was easily detectable in all fetal liver samples tested, but was not detectable in an adult liver sample. The $\gamma: \beta$ mRNA ratio was $>5: 1$ in the samples derived from 10-18-wk fetuses, but the ratio was considerably less after the 18 th week of gestation. $\beta$ globin mRNA could not be detected in $\mathrm{K} 562$ cells, consistent with previous reports $(30,31)$, but was abundant in adult erythroid marrow RNA derived from the same patient described above.

The same RNAs were next analyzed with probes derived from the human $\zeta$ and $\alpha$ globin genes (Fig. 2). The organization of these probes is shown at the bottom of this figure. Note that the nucleotide sequences of exons 1,2 , and 3 of the $\zeta, \alpha$, and $\theta$ globin gene exhibit $<80 \%$ identity in the regions from which the probes were derived; each probe is therefore specific for its mRNA using the hybridization conditions listed in Methods. $20 \mu \mathrm{g}$ of RNA from each sample was hybridized with the $\zeta$ globin probe, and the autoradiograph was exposed for $1 \mathrm{~d}$ (Fig. 2, upper panel). Correctly initiated $\zeta$ globin mRNA protected a probe fragment of $108 \mathrm{nt}$ from $S_{1}$ digestion. Small amounts of $\zeta$ globin mRNA were present in the earliest fetal liver samples, and gradually declined with development. $\zeta$ mRNA was abundant in K562 cells, and increased slightly with hemin induction. No $\zeta$ globin transcripts were detected in adult human liver or in adult bone marrow RNA derived from our patient with sickle cell anemia.

The relative abundance of $\alpha$ globin transcripts present in the same RNA samples is shown in Fig. 2 (middle panel). 2.5 $\mu \mathrm{g}$ of total cellular RNA from each sample was hybridized with the $\alpha_{2}$ globin probe, and subjected to $S_{1}$ nuclease analysis. A probe fragment of $180 \mathrm{nt}$ was protected from $S_{1}$ digestion by correctly spliced exons 2 of the $\alpha_{2}$ and $\alpha_{1}$ globin genes, which have the same nucleotide sequence (32). Abundant $\alpha$ transcripts were present in all stages of fetal development, but gradually declined in older fetal samples, paralleling the decline seen with the $\gamma$ and $\beta$ globin transcripts. No $\alpha$ mRNA was detected in adult liver. A small amount of $\alpha$ globin mRNA was detected in $\mathrm{K} 562$ cells, but abundant $\alpha$ mRNA was present in adult erythroid bone marrow.

The results of the $\theta$ globin mRNA analysis are presented in Fig. 3. Correctly processed $\theta$ globin exon 3 is expected to protect a probe fragment of $151 \mathrm{nt}$ from $S_{1}$ digestion. Longer probe fragments consistent with splicing intermediates were also detected using with this probe (data not shown); the levels of these intermediates paralleled levels of correctly spliced $\theta$ mRNA. The autoradiographs depicted in Fig. 3 were exposed for $5 \mathrm{~d}$. Since $20 \mu \mathrm{g}$ of RNA was analyzed, the relative sensitivity of the $\theta$ mRNA assay was 40 times that of the $\alpha$ mRNA analysis. Small amounts of $\theta$ globin mRNA are present in early fetal liver samples and gradually decline during development, consistent with the patterns seen for all the other globin genes. K562 cells contain $\theta$ globin mRNA, and the level increases slightly with two days of hemin treatment. $\theta$ globin mRNA is most abundant in adult erythroid bone marrow derived from the patient with homozygous sickle cell anemia, but was not detected in normal bone marrow RNA, consistent with a previous report (17). In a separate experiment, the sickle cell marrow sample was found to contain at least 10 times more $\gamma$ globin mRNA than the normal marrow sample (data not shown). Since both individuals had $<2 \%$ circulating fetal hemoglobin, we presume that this difference is due to the enrichment of erythroid precursors in the sickle cell marrow sample. Analysis of bone marrow RNA derived from four individuals with homozygous $\beta$ thalassemia revealed essentially the same relative abundance of $\theta$ globin mRNA (Fig. $3 B$ ). No $\zeta$ globin transcripts were detected in any of the bone marrow samples, even though $\zeta$ mRNA is more abundant than $\theta$ in K562 cells (compare lanes 1,2 vs. 3-8 in Fig. $3 B$ ).

In order to accurately represent the relative abundance of each globin mRNA at various stages of development, we simultaneously end-labeled all six globin probes to approximately the same specific activity, and analyzed RNA derived from 10- and 18-wk fetal livers or adult erythroid bone marrow. $2.5 \mu \mathrm{g}$ of each RNA was hybridized against the panel of all six globin probes, and $S_{1}$ nuclease protection analysis was performed. The gel was autoradiographed for $1 \mathrm{~d}$, and the results are presented in Fig. 4. The data presented in this figure were densitometrically scanned, revealing a $\gamma: \beta$ globin mRNA ratio of 6.0:1.0 at $10 \mathrm{wk}, 6.7: 1.0$ at $18 \mathrm{wk}$, and 0.02:1.0 in the adult bone marrow sample. The relative abundance of human $\alpha$ globin mRNA is approximately $50 \%$ that of $\gamma+\beta$. This result is somewhat different from the studies of Lodish (33, 34), Hunt et al. (35), and Benz et al. (36), who demonstrated that rabbit and human reticulocytes and bone marrow cells possess an $\alpha: \beta$ globin mRNA ratio of $\sim 1.2-2.0: 1.0$. Our studies were not designed to compare quantitatively $\alpha$-like to $\beta$-like 

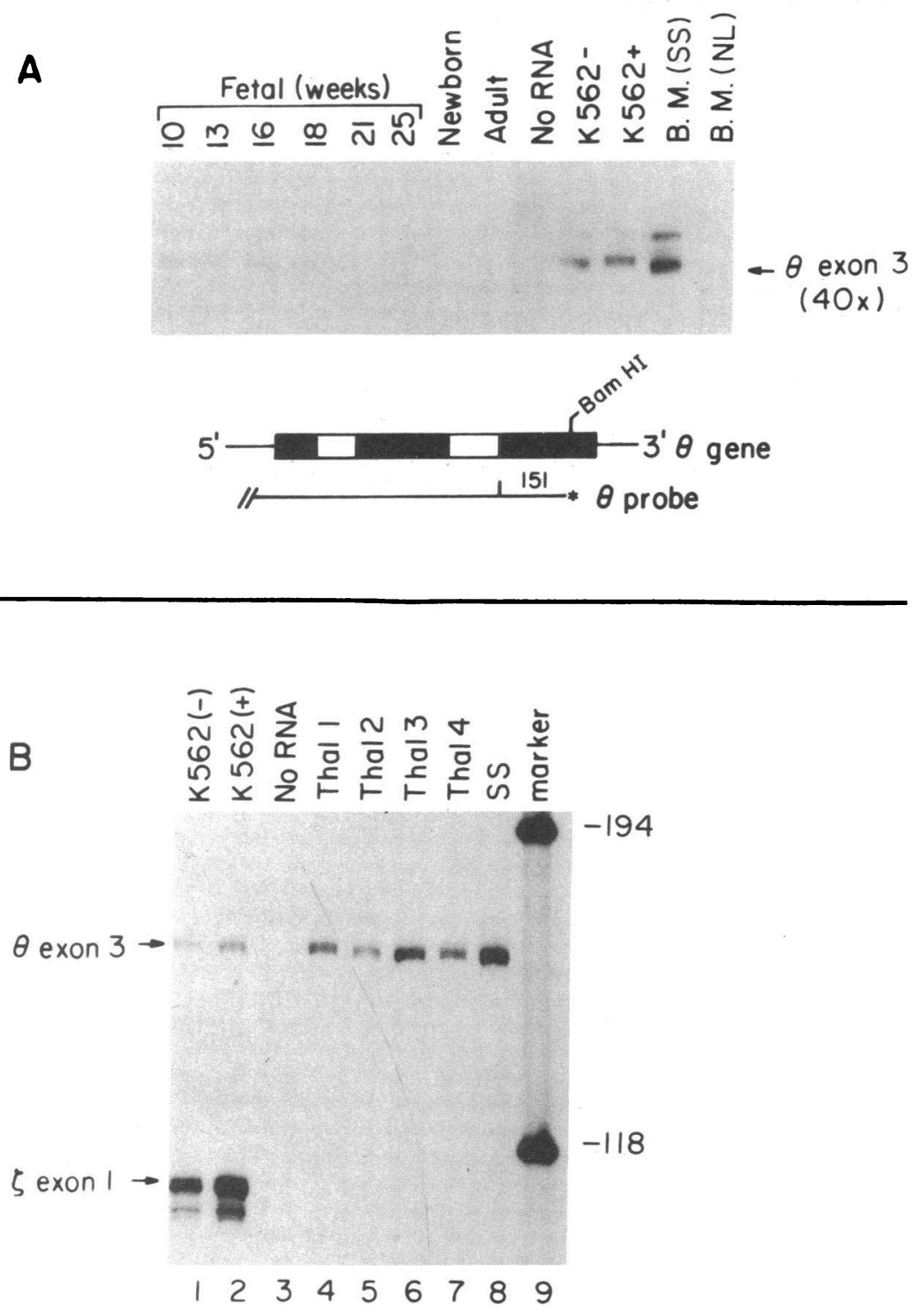

Figure 3. $S_{1}$ nuclease protection analysis of $\theta$ globin mRNA. The organization of the $\theta$ globin gene and the $\theta$ globin probe are shown in the bottom of $A .20 \mu \mathrm{g}$ of total cellular RNA was annealed with the $\theta$ globin probe, and analyzed as described in Fig. 1. (B.M. (SS)) Bone marrow RNA derived from a patient with sickle cell anemia; (B.M. $(N L)$ ) bone marrow RNA derived from a normal volunteer. The autoradiograph was exposed for $5 \mathrm{~d}$. In $B, 20 \mu \mathrm{g}$ of total cellular RNA was annealed simultaneously with the $\theta$ and $\zeta$ globin probes (see Fig. 2 ) and analyzed as described. Lanes 4-7 contain bone marrow RNA derived from four unrelated patients with homozygous $\beta$-thalassemia, and lane 8 RNA from an individual with homozygous sickle cell anemia. None of the patients had concomitant $\alpha$-thalassemia.

globin mRNA levels. The $\alpha$ - and $\beta$-like probes have different $5^{\prime}$ overhangs (and therefore have slightly different specific activities), and the lengths of probe-RNA duplexes are different (209 base pairs for the $\beta$-like probes, or 109,181 , or 151 for $\zeta$, $\alpha$, and $\theta$, respectively). It is therefore difficult to make comparisons of absolute mRNA levels except for the $\beta$-like genes, which possess identical labeled ends and duplex lengths. Nonetheless, these data clearly demonstrate that $\gamma, \beta$, and $\alpha$ globin are major mRNAs, and $\zeta, \epsilon$, and $\theta$ globin are minor mRNAs in fetal and adult erythroid cells.

The same RNAs used for the preceding $S_{1}$ analyses were also examined with control nonglobin probes; $5 \mu \mathrm{g}$ of total cellular RNA was slotted in triplicate onto nitrocellulose filters and subsequently hybridized to three different uniformly labeled probes (Fig. 5). The relative abundance of $\beta$-actin mRNA in fetal liver samples gradually declines with development. In contrast, the relative abundance of ceruloplasmin mRNA reaches a peak in mid-gestation, declines, and then dramatically increases in abundance in the newborn and adult liver samples. Ceruloplasmin mRNA is not detected in K562 cells, but is present in adult erythroid marrow, reflecting the ceruloplasmin mRNA present in bone marrow macrophages (27). c-myc exon 2 mRNA is present in trace amounts in early fetal liver samples. It is abundant in the rapidly dividing K562 cells, but is barely detected in hemin-induced K562 cells (23) or adult erythroid bone marrow samples.

\section{Discussion}

In this study, we isolated RNA from several fetal and adult liver samples that were stored at $-90^{\circ} \mathrm{C}$ for up to $20 \mathrm{yr}$ before RNA preparation. The ability to harvest RNA from these samples allowed us to examine globin RNA content at several points during gestation. We have shown that the relative abundance of globin mRNA is greatest in early fetal livers, and gradually declines to minimal levels in newborn liver. The relative abundance of each globin mRNA species parallels the relative abundance of newly synthesized globin proteins, as previously measured by several investigators (9-13). The embryonic globin genes were expressed at highest levels in early fetal liver samples, and their expression declined to undetectable levels in adult bone marrow. The newly discovered $\theta$ glo- 


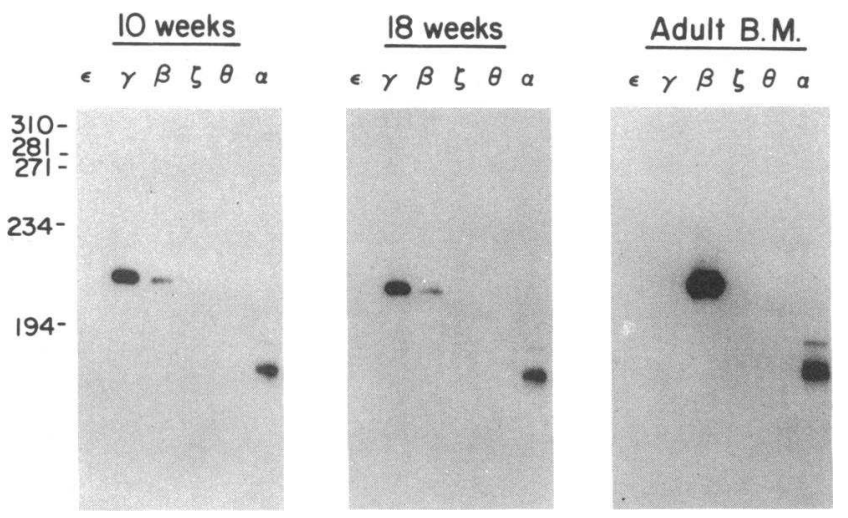

Figure 4. Simultaneous analysis of RNA samples with all six globin probes. All of the globin probes depicted in Figs. 1, 2, and 3 were simultaneously end-labeled to an approximate specific activity of 5 $\times 10^{6} \mathrm{cpm} / \mu \mathrm{g}$ of input DNA. All of the probes used in this study have four base $5^{\prime}$ overhangs that are labeled on the antisense strand only. $50,000 \mathrm{cpm}$ of each probe was annealed with $2.5 \mu \mathrm{g}$ of RNA derived from 10-wk fetal liver, 18-wk fetal liver, or with bone marrow from a patient with homozygous sickle cell anemia. After $S_{1}$ treatment and electrophoresis, autoradiography was performed for one day. The positions of simultaneously run molecular weight markers (in nucleotides) is shown at the left. The region of the gel containing correctly initiated $\zeta$ globin transcripts (108 nt) is not shown; no bands were seen in this region.

bin gene (14-18) is also expressed at low levels in fetal liver samples, but its mRNA is most abundant in bone marrow cells derived from adult patients with sickle cell anemia or $\beta$-thalassemia.

The relative abundance of all the globin $\mathrm{mRNAs}$ was greatest in fetal liver samples derived from embryos of 10 or 13 wk gestation but subsequently declined, consistent with the notion that the relative proportion of erythroid cells gradually diminishes during fetal liver development. The presence of erythroid precursors in human fetal livers of 5-20 wk gestation has been demonstrated by a number of workers based on routine morphologic analysis, including electron micrography (37-39). Several studies have demonstrated that erythropoietic precursors are at least as abundant as hepatic parenchymal cells in mid-gestational fetal livers; myeloid precursors comprise a much smaller fraction of the cells (40-42). In the only quantitative morphometric analysis of cell populations during rat fetal liver development, Greengard et al. (43) found that hematopoietic cells accounted for about $60-70 \%$ of total liver cells at mid-gestation, decreasing to about $50 \%$ at term and to less than $5 \%$ in the early postnatal livers. All of these studies are consistent with our findings of gradually declining globin mRNA abundance in older fetal livers, owing to reduced numbers of erythroid precursors in these samples.

The $\gamma: \beta$ globin mRNA ratio is approximately $6-7: 1$ between 10 and $18 \mathrm{wk}$ of gestation, and the ratio appears to gradually decline until it is approximately equivalent in newborn liver. Neither $\gamma$ nor $\beta$ mRNA was detected in adult liver cells, and the $\gamma: \beta$ mRNA ratio was $0.02: 1.0$ in adult erythroid tissue derived from a patient in whom $\sim 2 \%$ of the circulating hemoglobin was fetal. These data corroborate a number of studies that described rates of globin biosynthesis in the livers and reticulocytes of fetuses at various stages of development. These studies generally revealed that newly synthesized $\beta$ glo-

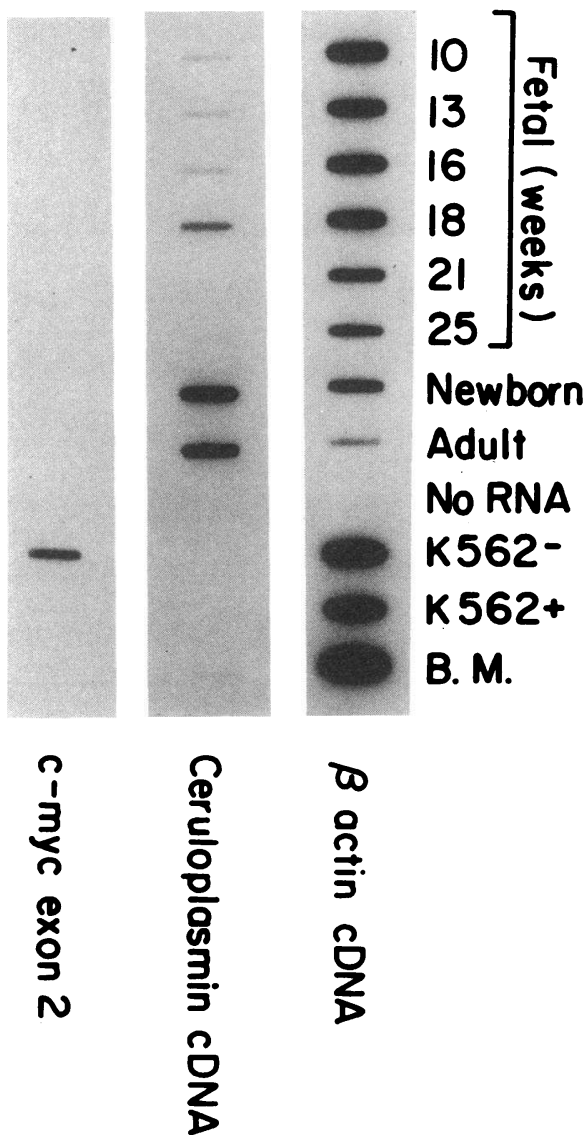

Figure 5. Slot blot analysis of $\beta$-actin, ceruloplasmin, and c-myc mRNAs. $5 \mu \mathrm{g}$ of total cellular RNA derived from each sample was slotted in triplicate onto nitrocellulose, dried, and baked. The filters were prehybridized, and $1 \times 10^{7} \mathrm{cpm}$ of each random primer labeled DNA was hybridized with each filter at $42^{\circ} \mathrm{C}$ overnight. After washing, autoradiography was performed for $24 \mathrm{~h}$.

bin chains could be detected as early as 8-10 wk of gestation, that $\beta$ globin comprised $5-15 \%$ of hemoglobin in mid-gestational fetuses, and that $\beta$ globin levels gradually increased in older samples (9-13). The $\gamma: \beta$ mRNA ratio of $6-7: 1$ defined in this study corresponds closely with these measurements of protein synthetic rates, and therefore suggests that the relative amount of $\gamma$ and $\beta$ globin protein synthesis is determined by the relative abundance of each mRNA. In turn, the abundance of each globin mRNA is probably controlled by the relative rate of transcription of each gene, since the half-lives of globin mRNAs are long $(1,2)$. Forrester, Groudine and colleagues (44) provided direct evidence for transcriptional regulation by demonstrating a higher rate of $\gamma$ globin gene transcription than $\beta$ in staged mid-gestational fetal livers. Together, these studies suggest that biosynthesis of the $\beta$-like globin chains may be regulated at the level of transcription in vivo.

We detected mRNA derived from the embryonic globin genes $(\epsilon$ and $\zeta)$ at all stages of fetal liver development, even though the relative abundance of these transcripts was very low compared with $\gamma, \beta$, or $\alpha$ globin mRNAs. We suspect that a small number of residual yolk sac-derived erythroblasts may be present in the 10- and 13-wk fetal liver samples, since embryonic red cells have previously been identified in 8-10-week fetal liver samples (13). However, no embryonic erythroblasts 
should be present in the older fetal liver samples. The most likely explanation for persistent $\epsilon$ and $\zeta$ globin gene expression in the older samples would therefore seem to be low-level transcription of these genes in fetal erythroblasts. These data are consistent with the recent finding of $\epsilon$ globin chains in blood samples obtained from 9-31-wk fetuses (45). However, we could not detect $\epsilon$ or $\zeta$ globin transcripts in bone marrow RNAs derived from several patients with erythroid hyperplasia. Again, these results are corroborated by recent studies that did not detect embryonic globin proteins in normal adult blood samples using monoclonal antibodies directed against the embryonic globin chains $(45,46)$.

Very small amounts of correctly spliced $\theta$ globin transcripts are present in all fetal liver samples and in adult erythroid bone marrow cells. The $\theta$ globin gene therefore appears to be co-regulated with the $\alpha$ globin genes, but is always expressed at lower levels. The $\delta$ globin gene, which encodes the $\beta$-like chain that contributes to the formation of hemoglobin $\mathrm{A}_{2}\left(\alpha_{2} \delta_{2}\right)$, is coregulated with the $\beta$ globin gene, but is always expressed at much lower levels, since this gene is dysfunctional or "thalassemic" (47). Since the $\theta$ globin gene is co-regulated with the linked $\alpha$ globin genes, but expressed at much lower levels, the relationship between $\theta$ and $\alpha$ globin gene expression is reminiscent of the relationship between $\delta$ and $\beta$ globin gene expression.

$\theta$-Globin mRNA is present in the human erythroleukemia cell line K562. Despite the "embryonic-fetal" phenotype of K562 cells, $\delta$ globin transcripts ("adult"-like) are also present in these cells (30). The finding of $\theta$ globin transcripts in K562 cells is therefore consistent with their fetal-adult pattern of expression in vivo. Recently, Leung et al. (17) and Hsu et al. (18) reported the presence of correctly initiated and correctly terminated $\theta$ globin transcripts in K562 cells. In addition, Leung and colleagues also detected trace amounts of $\theta$ globin mRNA in yolk sac-derived cells and in a fetal liver sample of unspecified age. No $\theta$ globin mRNA could be detected in normal adult bone marrow RNA samples examined in their study or in ours. However, bone marrow samples derived from patients with sickle cell anemia or homozygous $\beta$-thalassemia did contain small amounts of $\theta$ globin mRNA. Since these marrows are usually more than $80 \%$ erythroid, erythroid-specific mRNAs may be enriched manifold in these samples when compared with normal marrow. For this reason, we suspect that the ability to detect $\theta$ globin transcripts in these marrows is due to the enrichment of erythroid cells that contain $\theta$ globin mRNA, not abnormal regulation of this gene. However, the possibility exists that this gene may be activated in the erythroid precursors of patients with accelerated erythropoeisis.

Because $\theta$ globin mRNA is a minor transcript at all stages of development, we are not surprised that deletion of this gene does not lead to an identifiable phenotype $(48,49)$. The relative abundance of this mRNA is always less than $1 \%$ that of $\alpha$ globin, and thus it could only participate in the formation of a minor hemoglobin. The presence of this globin in fetal or adult red cells remains speculative, since no candidate molecules have yet been identified. Further studies will be required to determine whether this apparently functional mRNA is in fact translated into $\theta$ globin chains.

In conclusion, this study provides further evidence that rates of hemoglobin biosynthesis in vivo are probably determined by the relative abundance of each globin mRNA; that is, hemoglobin "switching" is probably mediated at the level of transcription. Presumably, soluble protein factors (50) and a regulatory "clock" (51) are both partially responsible for transcriptional switching, but the precise nature of this event remains unknown. Studies comparing transcriptional factors in fetal and adult erythroid cells will hopefully yield clues regarding the molecular basis of this process.

\section{Acknowledgments}

The authors wish to thank Drs. N. J. Proudfoot, E. Whitelaw, and D. Higgs for providing the $\theta$ globin gene, Dr. Jonathan Gitlin for the gift of human ceruloplasmin cDNA, and Diana Horn for preparing this manuscript.

Dr. Ley was supported by National Institutes of Health DK-38682, the March of Dimes Basil O'Connor Fund, and the Colonel Sanders Memorial Fund. Dr. Schwartz and Dr. Gordon are Established Investigators of American Heart Association.

\section{References}

1. Nienhuis, A. W., N. P. Anagnou, and T. J. Ley. 1984. Advances in thalassemia research. Blood. 63:738-758.

2. Stamatoyannopoulos, G., and A. W. Nienhuis. 1987. Hemoglobin switching. In The Molecular Basis of Blood Diseases. G. Stamatoyannopoulos, A. W. Nienhuis, P. Leder, and P. W. Majerus, editors. W. B. Saunders Co., Philadelphia. 66-105.

3. Peschle, C., F. Mavilio, A. Care, G. Migliaccio, A. R. Migliaccio, G. Salvo, P. Samoggia, S. Petti, R. Guerriero, M. Marinucci, D. Lazzaro, G. Russo, and G. Mastroberardino. 1985. Hemoglobin switching in human embryos: asynchrony of $\zeta \rightarrow \alpha$ and $\epsilon \rightarrow \gamma$-globin switches in primitive and definitive erythropoietic lineage. Nature (Lond.). 313:235-238.

4. Migliaccio, G., A. R. Migliaccio, S. Petti, F. Mavilio, G. Russo, D. Lazzaro, U. Testa, M. Marinucci, and C. Peschle. 1986. Human embryonic hemopoiesis: kinetics of progenitors and precursors underlying the yolk sac $\rightarrow$ liver transition. J. Clin. Invest. 78:51-60.

5. van der Ploeg, L. H. T., and R. A. Flavell. 1980. DNA methylation in the human $\gamma \delta \beta$-globin locus in erythroid and nonerythroid tissues. Cell. 19:947-958.

6. Mavilio, F., A. Giampaolo, A. Care, G. Migliaccio, M. Calandrini, G. Russo, G. L. Pagliardi, G. Mastroberardino, M. Marinucci, and C. Peschle. 1983. Molecular mechanisms of human hemoglobin switching: selective undermethylation and expression of globin genes in embryonic, fetal, and adult erythroblasts. Proc. Natl. Acad. Sci. USA. 80:6907-6911.

7. Ley, T. J., J. DeSimone, N. P. Anagnou, G. H. Keller, R. K. Humphries, P. H. Turner, N. S. Young, P. Heller, and A. W. Nienhuis. 1982. 5-azacytidine selectively increases $\gamma$-globin synthesis in a patient with $\beta+$ thalassemia. N. Engl. J. Med. 307:1469-1475.

8. Weatherall, D. J., M. E. Pembrey, and J. Pritchard. 1974. Fetal hemoglobin. Clin. Haematol. 3:467-508.

9. Thomas, E. D., H. L. Lochte, Jr., W. B. Greenough III, and M. Wales. 1960. In vitro synthesis of foetal and adult hemoglobin by foetal hematopoietic tissues. Nature (Lond.). 185:396-397.

10. Pataryas, H. A., and G. Stamatoyannopoulos. 1972. Hemoglobins in human fetuses: evidence for adult hemoglobin production after the 11th gestational week. Blood. 39:688-696.

11. Kazazian, H. H., Jr., and A. P. Woodhead. 1973. Hemoglobin A synthesis in the developing fetus. N. Engl. J. Med. 289:58-62.

12. Wood, W. G., and D. J. Weatherall. 1973. Hemoglobin synthesis during human foetal development. Nature (Lond.). 244:162-165.

13. Papayannopoulou, T., T. H. Shepard, and G. Stamatoyannopoulos. 1983. Studies of hemoglobin expression in erythroid cells of early human fetuses using anti- $\gamma$ and anti- $\beta$-globin chain fluorescent antibodies. In Globin Gene Expression and Hematopoietic Differentiation. G. Stamatoyannopoulos and A. W. Nienhuis, editors. Alan R. Liss, Inc., New York. 421-430. 
14. Marks, J., J.-P. Shaw, and C.-K. J. Shen. 1986. The orangutan adult $\alpha$-globin gene locus: duplicated functional genes and a newly detected member of the primate $\alpha$-globin gene family. Proc. Natl. Acad. Sci. USA. 83:1413-1417.

15. Marks, J., J.-P. Shaw, and C.-K. J. Shen. 1986. Sequence organization and genomic complexity of primate $\theta_{1}$ globin gene, a novel $\alpha$-globin-like gene. Nature (Lond.). 321:785-788.

16. Shaw, J.-P., J. Marks, and C.-K. J. Shen. 1987. Evidence that the recently discovered $\theta_{1}$-globin gene is functional in higher primates. Nature (Lond.). 326:717-720.

17. Leung, S., N. J. Proudfoot, and E. Whitelaw. 1987. The gene for $\theta$-globin is transcribed in human fetal erythroid tissues. Nature (Lond.). 329:551-554.

18. Hsu, S.-L., J. Marks, J.-P. Shaw, M. Tam, D. R. Higgs, C. C. Shen, and C.-K. J. Shen. 1988. Structure and expression of the human $\theta_{1}$ globin gene. Nature (Lond.). 331:94-96.

19. Schwartz, A. L., C. J. Steer, and E. S. Kempner. 1984. Functional size of the human asialoglycoprotein receptor as determined by radiation inactivation. J. Biol. Chem. 259:12025-12029.

20. Schwartz, A. L., N. C. R. Raiha, and T. W. Rall. 1975. Hormonal regulation of glycogen metabolism in human fetal liver I. Normal development. Diabetes. 24:1101-1112.

21. Breitfeld, P. P., and A. L. Schwartz. 1985. Cell-free synthesis and co-translational processing of the human asialoglycoprotein receptor. Eur. J. Biochem. 150:409-414.

22. Collins, S., and M. Groudine. 1983. Rearrangement and amplification of c-abl sequences in the human chronic myelogenous leukemia cell line K-562. Natl. Proc. Acad. Sci. USA. 80:4813-4817.

23. Gimble, J. M., E. E. Max, and T. J. Ley. 1988. High resolution analysis of the human gamma globin gene promoter in K562 erythroleukemia cell chromatin. Blood. 72:606-612.

24. Chomczynski, P., and N. Sacchi. 1987. Single-step method of RNA isolation by acid guanidinium thiocyanate-phenol-chloroform extraction. Anal. Biochem. 162:156-159.

25. Feinberg, A. P., and B. Vogelstein. 1984. A technique for radiolabelling DNA restriction endonuclease fragments to high specific activity. Anal. Biochem. 137:266-267.

26. Ponte, P., S.-Y. Ng, J. Engel, P. Gunning, and L. Kedes. 1984. Evolutionary conservation in the untranslated regions of actin mRNAs: DNA sequence of a human $\beta$-actin cDNA. Nucleic Acids Res. 12:1687-1696.

27. Gitlin, J. D. 1988. Transcriptional regulation of ceruloplasmin gene expression during inflammation. J. Biol. Chem. 263:6281-6287.

28. Colby, W. W., E. Y. Chen, D. H. Smith, and A. D. Levinson. 1983. Identification and nucleotide sequence of a human locus homologous to the v-myc oncogene of avian myelocytomatosis virus MC29. Nature (Lond.). 301:722-725.

29. Favaloro, J., R. Treisman, and R. Kamen. 1980. Transcription maps of polyoma specific RNA analysis by two-dimensional nuclease $S_{1}$ gel mapping. Methods Enzymol. 65:618-749.

30. Dean, A., T. J. Ley, R. K. Humphries, M. Fordis, and A. N. Schechter. 1983. Inducible transcription of five globin genes in K562 human leukemia cells. Proc. Natl. Acad. Sci. USA. 80:5515-5519.

31. Miller, C. W., K. Young, D. Dumenil, B. P. Alter, J. M. Schofield, and A. Bank. 1984. Specific globin mRNAs in human erythroleukemia (K562) cells. Blood. 63:195-200.

32. Michaelson, A. M., and S. H. Orkin. 1983. Boundaries of gene conversion within the duplicated human $\alpha$-globin genes. J. Biol. Chem. 258:15245-15254.
33. Lodish, H. F. 1971. Alpha and beta globin messenger ribonucleic acid. J. Biol. Chem. 246:7131-7138.

34. Lodish, H. F., and M. Jacobsen. 1972. Regulation of hemoglobin synthesis. J. Biol. Chem. 247:3622-3629.

35. Hunt, D. M., D. R. Higgs, J. M. Old, J. B. Clegg, D. J. Weatherall, and G. W. Marsh. 1980. Determination of alpha thalassaemia phenotypes by messenger RNA analysis. Br. J. Haematol. 45:53-64.

36. Benz, E. J., Jr., J. Pritchard, D. Hillman, J. Glass, and B. G. Forget. 1984. $\beta$-globin messenger RNA content of bone marrow erythroblasts in heterozygous $\beta$-thalassemia. Am. J. Hematol. 16:33-45.

37. Zamboni, L. 1965. Electron microscopic studies of blood embryogenesis in humans. Ultrastruct. Res. 12:525-541.

38. Kimura, N., Y. Yamano, Y. Niho, and T. Yanase. 1983. Multipotent hemopoietic progenitors $\left(\mathrm{CFU}_{\mathrm{mix}}\right)$ in human fetal liver. Exp. Hematol. 11:849-855.

39. Petti, S., U. Testa, A. R. Migliaccio, F. Mavilio, M. Marinucci, D. Lazzaro, G. Russo, G. Mastroberardino, and C. Peschle. 1985. Embryonic hemopoiesis in human liver: morphologic aspects at sequential stages of ontogenic development. In Fetal Liver Transplantation. R. P. Gale, J. L. Touraine, and G. Lucarelli, editors. Alan R. Liss, Inc., New York. 57-71.

40. Thomas, D. B., and J. M. Yoffey. 1964. Hepatic hematopoiesis in the human foetus. Br. J. Haematol. 10:193-197.

41. Sharma, S., M. Bhargava, and V. Kochupillai. 1985. Morphological pattern of hematopoiesis in human fetal liver. In Fetal Liver Transplantation. R. P. Gale, J. L. Touraine, and G. Lucarelli, editors. Alan R. Liss, Inc., New York. 167-171.

42. Adam, P. A. J., A. L. Schwartz, E. L. Rahiala, and M. P. Kekomaki. 1978. Glucose production in midterm human fetus. I. Autoregulation and hormonal regulation of glucose output by the isolated perfused liver. Am. J. Physiol. 234:560-567.

43. Greengard, O., M. Federman, and W. E. Knox. 1972. Cytomorphometry of developing fetal liver and its application to enzymic differentiation. J. Cell Biol. 52:261-272.

44. Forrester, W. C., C. Thompson, J. T. Elder, and M. Groudine. 1986. A developmentally stable chromatin structure in the human $\beta$-globin gene cluster. Proc. Natl. Acad. Sci. USA. 83:1359-1363.

45. Zhao, J.-q., H.-y. Luo, B. J. Clarke, and D. H. K. Chui. 1988. An immunoassay to detect human embryonic $\epsilon$ globin chains by a murine monoclonal antibody. Blood. 71:883-887.

46. Chui, D. H. K., S. C. Wong, S.-W. Chung, M. Patterson, S. Bhargava, and M.-C. Poon. 1986. Embryonic $\zeta$-globin chains in adults: A marker for $\alpha$-thalassemia-1 haplotype due to a $>17.5-\mathrm{kb}$ deletion. N. Engl. J. Med. 314:76-79.

47. Humphries, R. K., T. J. Ley, P. Turner, A. D. Moulton, and A. W. Nienhuis. 1982. Differences in human $\alpha, \beta$, and $\delta$ globin gene expression in monkey kidney cells. Cell. 30:173-183.

48. J. B. Clegg. 1987. Can the product of the $\theta$ gene be a real globin? Nature (Lond.). 329:465-466.

49. Fei, Y. J., S. Fujita, and T. H. J. Huisman. 1988. Two different theta $(\theta)$ globin gene deletions observed among black newborn babies. Br. J. Haematol. 68:249-253.

50. Baron, M. H., and T. Maniatis. 1986. Rapid reprogramming of globin gene expression in transient heterokaryons. Cell. 46:591-602.

51. Papayannopoulou, T., M. Brice, and G. Stamatoyannopoulos. 1986. Analysis of human hemoglobin switching in MEL $\times$ human fetal erythroid cell hybrids. Cell. 46:469-476. 